\title{
The Holocene evolution of the barrier and the back-barrier basins of Belgium and the Netherlands as a function of late Weichselian morphology, relative sea-level rise and sediment supply
}

\author{
Dirk J. Beets ${ }^{1,2}$ \& Adam J. F. van der Spek ${ }^{1}$ \\ Netherlands Institute of Applied Geoscience TNO - National Geological Survey, P.O.Box 80015, \\ 3508 TA Utrecht, the Netherlands \\ 2 corresponding author; e-mail: beets@worldonline.nl
}

Manuscript received: 15 December 1998; accepted in revised form: 18 August 1999

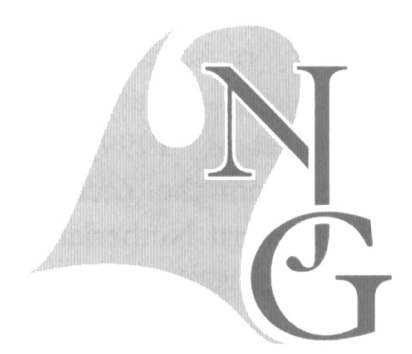

\begin{abstract}
Flooding of the southern part of the North Sea occurred between 9000 and $8000 \mathrm{BP}$, when the rate of relative sea-level rise was on the order of $0.7 \mathrm{~cm}$ per year for the Dover Strait Region and $1.6 \mathrm{~cm}$ per year for the area north of the Frisian Islands, forcing the shoreline to recede rapidly. When relative sea-level rise decelerated after $7000 \mathrm{BP}$ for the Belgian coast and 6000 BP for the central Netherlands coast, sediment supply by the tidal currents balanced the creation of accommodation space in the estuaries and other back-barrier basins. Consequently, the barrier started to stabilize, and the tidal basins and their inlets silted up. Between 5500 and $4500 \mathrm{BP}$, the Belgian coastal plain changed into a freshwater marsh with peat accumulation, and the same happened 500-1000 years later in the western provinces of the Netherlands. The E-W running barrier/back-barrier system of the Frisian Islands in the northern Netherlands stayed open until today, however, because of lower sediment supply.

The period between 4000 and $2000 \mathrm{BP}$ was relatively quiet due to the strong deceleration of the rate of sea-level rise; peat cushions developed behind the barriers, which were straightened by erosion of the headlands. Major and often catastrophic flooding occurred in the Middle Ages, when the estuaries in the southwestern part of the Netherlands formed.

About $226( \pm 15 \%) \times 10^{9} \mathrm{~m}^{3}$ sediment, mostly sand, is stored in the barriers and back-barrier basins of the Netherlands, $70 \%$ of which was deposited prior to $5000 \mathrm{BP}$. About $10 \%$ of the stored sediment is estimated to be of alluvial origin. Most of the sediment is derived by the erosion of the Pleistocene basement during recession of the barriers, but tide-induced crossshore transport from the North Sea forms an additional source for the barriers and back-barriers of the west-facing coast of the Netherlands.
\end{abstract}

Keywords: coastal plain development, estuaries, Rhine, sediment budget, tidal basins

\section{Introduction}

The coastal plains of Belgium and the Netherlands (Figs. 1, 2B) form the southern part of a Holocene barrier/back-barrier system along the southeastern and eastern coast of the North Sea (Fig. 1), bounded by the cliff coast of northern France in the south and the tip of Denmark in the north. At present, a large part of the back-barrier system consists of heavily populated, reclaimed and cultivated tidal flats, estuaries and marshes, situated at or below sea level and protected from flooding by man-made coastal structures and by dunes. Maintenance of this coastal defense remains one of the important Dutch issues. A joint, multidisciplinary project on large-scale and long-term development of the Dutch coast was started for this reason in 1986. It was carried out by a large group of scientists from universities, research institutes and government institutions. Many publications resulted, ranging in scope from the detailed mechanics of sediment-transport processes to the Holocene development of the coast. The present contribution briefly summarizes our present knowledge on the long-term development of the system. We will discuss the morphology of the coastal plain, the hydrodynamics, morphology and sediments of the Southern Bight (Fig. 1), the (variations in) relative sea-level (RSL) rise in the area, and the Holocene succession and his- 


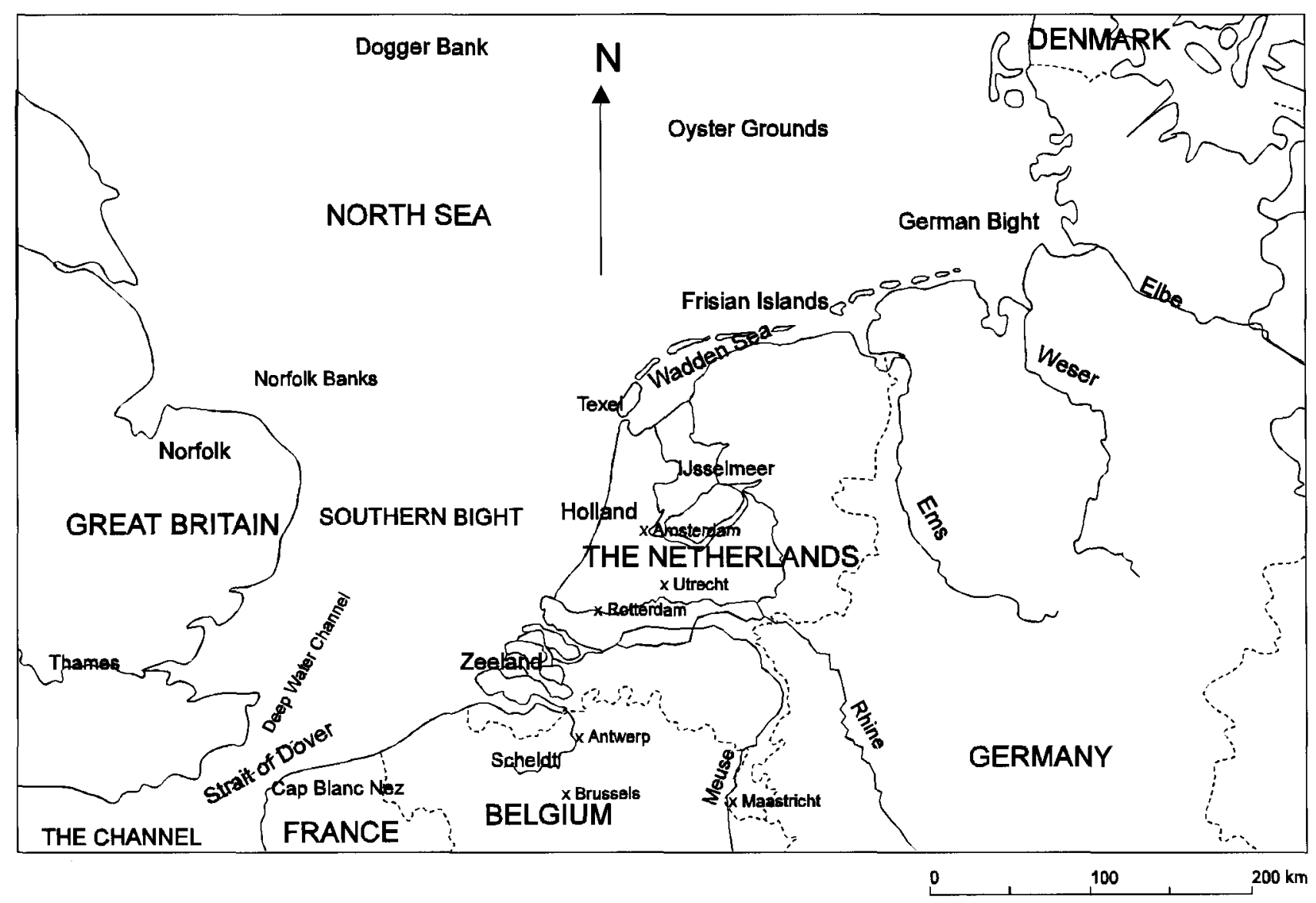

Fig. 1. Map of the study area with the locations of the geographical names used in the text.

tory of the coastal plain. Finally, we present a new, hypothetical model of sediment transport and accumulation in the Southern Bight and its effects on the coastal plain under study.

\section{Morphology of the coastal plain}

The Flemish and Dutch coast between Cap Blanc Nez (Fig. 1) in the south and the island of Texel (Fig. 1) in the north has a general SW-NE direction, concave towards the North Sea. North of Texel, the coastline turns to almost $\mathrm{E}-\mathrm{W}$. Although the present morphology is strongly modified by tides and waves, first-order features - such as this change in orientation of the coastline - are completely defined by the Pleistocene morphology. The coastal plain consists of a wedge-shaped succession of estuarine deposits, mainly medium- to fine-grained sand and mud, but also some peat. At the present coastline, this wedge varies in thickness from 15 to more than $30 \mathrm{~m}$. The coastal plain reaches its greatest width, about $100 \mathrm{~km}$, in the western Netherlands. Its thickness and width are defined by the westward slope of the pre-transgressional surface and the position of former channels. Slope gradients vary between 1:500 and 1:1000 for the base of the Belgian coastal plain and between
1:2500 and 1:4000 for that of the Netherlands (Fig. 2A).

The coastline between northern France and the southwestern Netherlands is closed and consists of a narrow barrier (Fig. 2B). Coastline erosion is prominent in the north near to the estuary of the river Scheldt (Fig. 1). Large estuaries of the rivers Rhine (Fig. 1), Meuse (Fig. 1) and Scheldt form the coastal system of the southwestern Netherlands. The inlets of these estuaries are up to $30 \mathrm{~m}$ deep. After the catastrophic floods of 1953, most of the inlets have been closed by dikes or sluices; others are protected during extremely high water by mobile storm shields. Barriers at the heads of the islands and peninsulas are narrow in comparison to that of the western coastal area (Holland) of the Netherlands (Figs. 1 and 2), and coastal erosion is prominent. The Holland' coastline is closed over a distance of about $120 \mathrm{~km}$. Except for the southern- and northernmost part of this coastline, the barrier consists of an up to $10-\mathrm{km}$ wide zone of prograded ridges and swales overlain by dunes. The barrier protects a wide coastal plain. The coast is and has been - eroding significantly in the north and in the south, but is more or less stable in its central part. Eroded sand in the south is transported northward by longshore drift, whereas that in the north dis- 


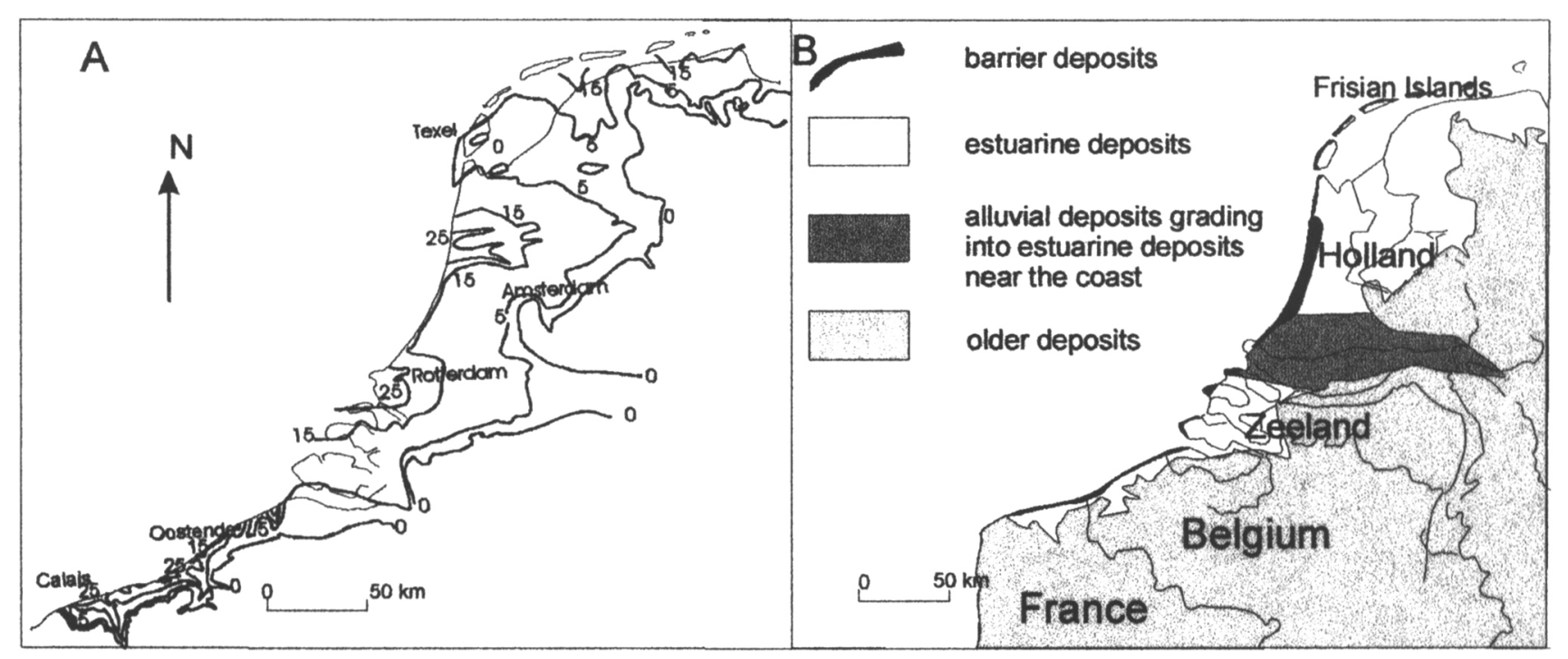

Fig. 2. Geological context.

A: depth to the base of the Holocene deposits (in meters below mean sea level) in the coastal plains of Northern France, Belgium and the Netherlands; after Houthuys et al. (1993) and De Gans \& Van Gijssel (1996).

B: main facies associations in the coastal plain of the Netherlands, Belgium and northern France.

appears by way of the inlet between Holland and the island of Texel (Fig. 1) into the Wadden Sea. The Frisian Islands (Fig. 1), separated by tidal inlets 20 $30 \mathrm{~m}$ deep, form the barrier of the Wadden Sea, a tidal basin separated by dikes from reclaimed land in the south. Overall, the North Sea coastline of the Frisian Islands is receding, but small-scale progradation occurs, although locally and temporarily (Oost \& De Boer, 1994; Oost, 1995). Each barrier island along the Wadden Sea consists of dunes on top of sandy shoal and channel deposits (Van der Spek, 1996).

\section{The Southern Bight}

The Southern Bight is the shallow, funnel-shaped inland sea enclosed between Great Britain to the west and Belgium and the Netherlands to the east (Fig. 1). It is situated in the temperate climatic zone, characterized by prevailing, commonly strong westerly winds. As shown by Van Straaten (1961), wind and wave climate of the bight are closely correlated. The significant wave height for the central part of the Holland coast is $1.3 \mathrm{~m}$ (Kroon, 1990). It increases northward to $1.8 \mathrm{~m}$ near the island of Texel (Sha, 1989) and decreases towards the south.

The tidal wave enters the Southern Bight both from the north and from the south (Fig. 3A). The tidal wave from the north splits north-east of Norfolk in a branch moving eastwards towards the Frisian Islands and one moving into the Southern Bight, where it rotates anticlockwise around an amphidromic point between Holland and Norfolk (Fig. 1). It joins in phase the tidal wave coming in through the Strait of Dover from the south, which has a large tidal range but, because of the narrow entrance, consists of a relatively small mass. From Cap Blanc Nez, the tidal range falls rapidly northward to less than $2 \mathrm{~m}$ along the southern part of the Dutch coast, and increases again along the northern part. North of the Frisian Islands, the southern and eastern branch of the tidal wave rejoin. The tidal wave in the study area is asymmetric with a shorter flood period; consequently, peak current velocities during flood are higher than during ebb (Dronkers, 1986). The resulting, small residual current causes northward sediment transport along the studied coast (McCave, 1971; Dronkers, 1986). The present northward-directed sand transport at a depth of $-20 \mathrm{~m}$ along the coast of the Netherlands is estimated to be $10-40 \mathrm{~m}^{3} \cdot \mathrm{m}^{-1} \cdot \mathrm{a}^{-1}$, based on processand behaviour-related model calculations (Van Rijn, 1995).

In general, tidal currents are strong along the British coast, in the narrow Southern Bight, and along the Frisian Islands, including those in the German Bight. Except for the 'Deep Water Channel' (Fig. 1 ), an up to $60 \mathrm{~m}$ deep depression running from the Norfolk to the Strait of Dover Banks (Figs. 1, 3), the Southern Bight has a water depth of less than $40 \mathrm{~m}$, and is characterised by groups of linear banks or ridges parallel or at a small angle to the main axis of the tidal-current ellipse (Houbolt, 1968; Kenyon et al,. 1981; Johnson et al., 1982; Berné et al., 1994; Collins et al., 1995), and complex fields of superposed subaqueous dunes perpendicular to that axis (McCave, 1971). The ridges may rise more than $30 \mathrm{~m}$ 


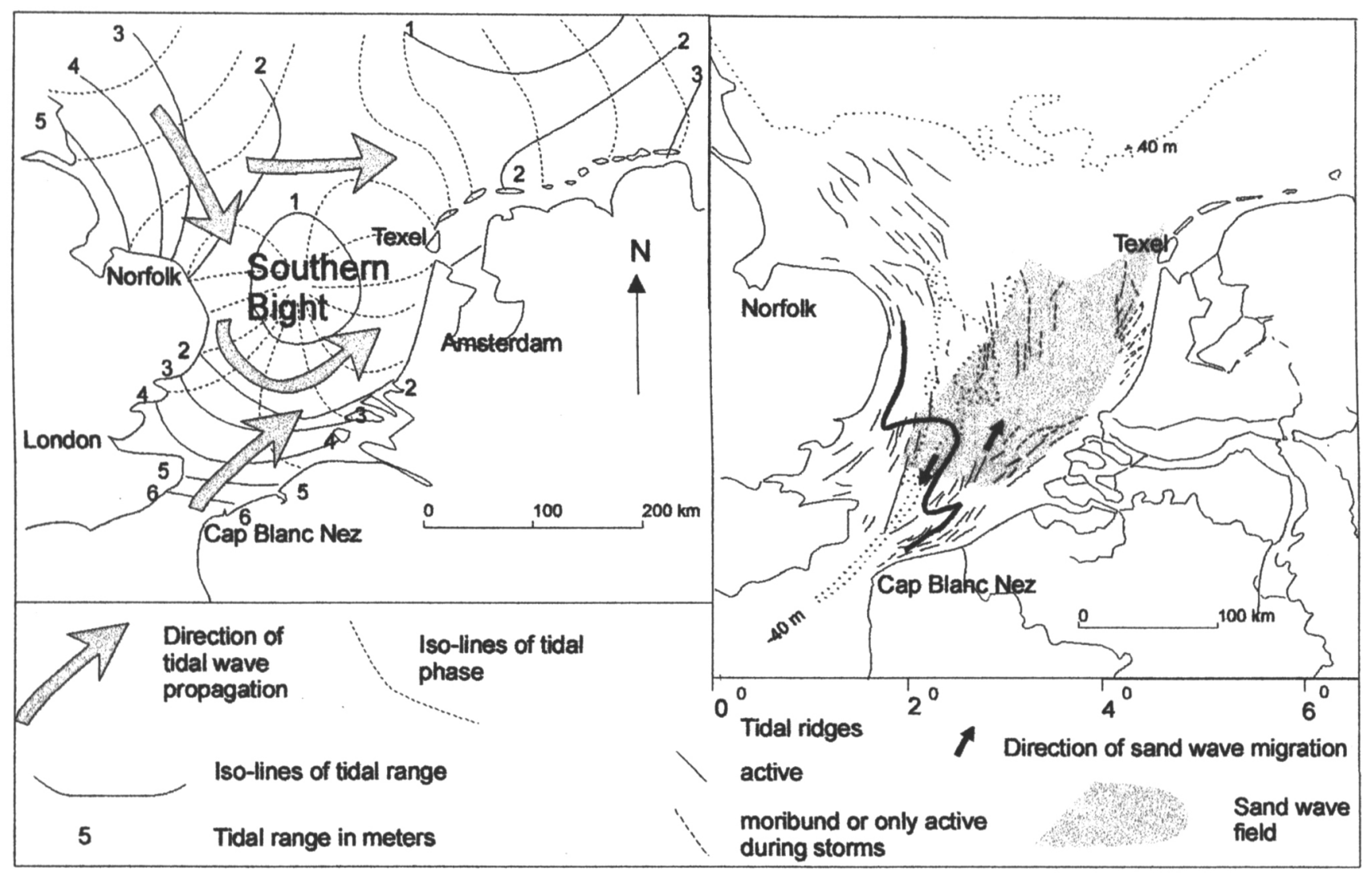

Fig. 3. Tides and tidal ridges.

A: path of the astronomical tide in the Southern Bight (southern North Sea).

B: locations of the tidal ridges and the sand wave field in the Southern Bight; the thick, wavy line between Norfolk and Cap Blanc Nez indicates the approximate boundary between northward and southward transport, as deduced from the sand-wave morphology; modified from McCave (1971) and Houbolt (1968).

above adjacent swales, and can reach to less than 10 $\mathrm{m}$ below sea level. They are several tens of kilometres long and $2-5 \mathrm{~km}$ wide. Most, if not all, of the Holocene sand in the southern North Sea is reworked from Pleistocene deposits. At present, the rivers surrounding the Southern Bight - as, for instance, Rhine and Meuse - only carry suspension to their mouths. As will be discussed below, it is not very likely that this was much different during most of the Holocene, as bed load as well as part of the suspended load was deposited in the alluvial plain to fill up the space created by the rapidly rising base level (= sea level). Tidal currents may well have transported sand from the Channel via the Strait of Dover into the Southern Bight during the early Holocene, when the southern North Sea was not yet connected to the northern North Sea. Both the orientation of the sand dunes in the Southern Bight (McCave, 1971; Johnson et al., 1982) and tidal modelling (Austin, 1991) show, however, that at present residual currents in the southern part of the Southern Bight promote export of sand to the Channel area (Fig. 3B).

Modelling of tide-induced sediment transport in the North Sea at sea level stands of $0 \mathrm{~m}$ (present),
$-5 \mathrm{~m}(5000-6000 \mathrm{BP})$ and $-15 \mathrm{~m}(7000-8000 \mathrm{BP})$, using a flow model based on the shallow-water equations and a depth-integrated transport model for suspended sediment, shows a dominance of erosion in the southern part of the Southern Bight and deposition to its north. The area of deposition is an E-W to SE-NW running, up to $100 \mathrm{~km}$ wide zone which in all three simulations has its southern boundary about halfway the Holland coast (Gerritsen \& Berentsen, 1998). The model for the present-day situation is in good agreement with the data on sediment transport and deposition in the Southern Bight. Little is known, however, of the sediment transport in the Southern Bight during most of the Holocene, so that we cannot confirm the results of the modelling at lower sea-level stands. As will be discussed below, our data indicate that not all sediment stored in the Holocene coastal plains of Belgium and the Netherlands comes from erosion of headlands during coastline recession or from an alluvial source. An important part of the sediment is thought to be derived from the Southern Bight, and a provenance mechanism as suggested by the modelling of Gerritsen \& Berentsen (1998) would fit well with this concept. 


\section{Relative sea-level rise and the flooding of the Southern Bight}

Differential glacio- and hydro-isostatic movements are reflected in the three RSL curves for the area, which show a southward decrease in rate of subsidence (Fig. 4A). The northernmost one, for the German Bight and the Oyster Grounds north of the Frisian Islands (Behre et al., 1979; Ludwig et al., 1979, 1981) has the highest rate of RSL rise prior to $7000 \mathrm{BP}$ and merges more or less with the one for the Holland coast (Jelgersma, 1961, 1979; Van de Plassche, 1982; Van de Plassche \& Roep, 1989) after that time. The RSL. curve for the Belgian coast (Denys \& Baeteman, 1995) lies originally above that for the Holland coast but joins it from about $3000 \mathrm{BP}$ onward.

The rate of RSL rise prior to $7000 \mathrm{BP}$ was in the order of $0.7 \mathrm{~cm} \cdot \mathrm{a}^{-1}$ for the Belgian coast and about 1.6 $\mathrm{cm} \cdot \mathrm{a}^{-1}$ for the area north of the Frisian Islands. At this high rate, the Southern Bight flooded rapidly (Fig. 4B).
At $8500 \mathrm{BP}$, the Southern Bight was still isolated from the northern North Sea; at its southeastern side, the sea had reached the Belgian coastal plain (Denys \& Baeteman, 1995). Around $8000 \mathrm{BP}$, the sea invaded the depressions in the coastal plain of the western Netherlands but it was still north of the Frisian Islands. By then, the Southern Bight and the northern North Sea were connected, but the present-day Dogger Bank still formed a large island in between. Considering the slight dip of the pre-transgressional surface, we assume that, at $8500 \mathrm{BP}$, the size of the Southern Bight was sufficient to produce waves at its eastern shores capable of building a protective barrier behind which a complex of estuaries and tidal basins could develop.

\section{The development of the coastal plains of Bel- gium and the Netherlands}

The Holocene development of the coastal plain is controlled mainly by the morphology of the flooded

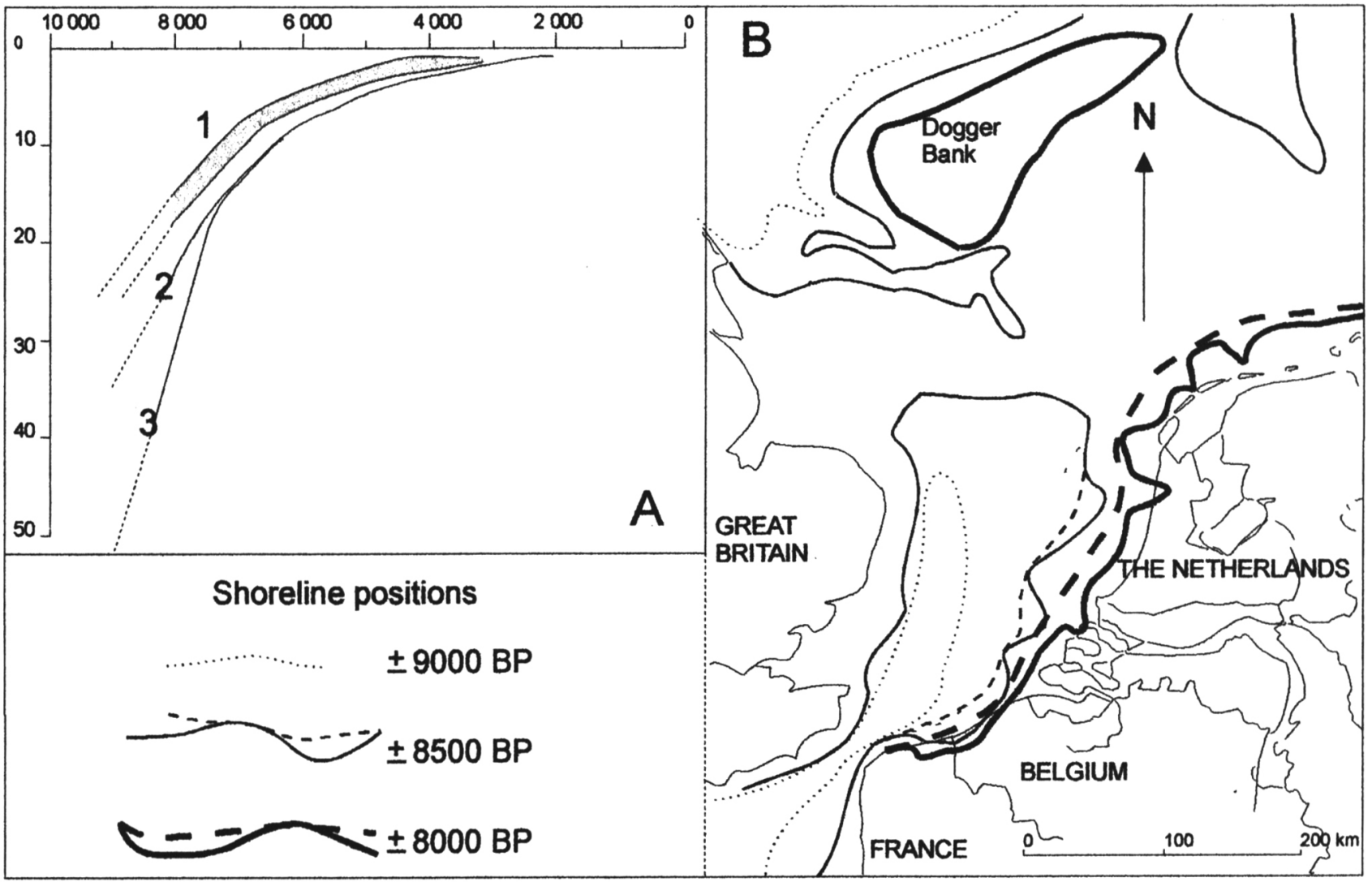

Fig. 4. Sea-level rise and resulting flooding history.

A: time/depth plot of RSL rise for (1) the Belgian coastal plain, after Denys \& Baeteman (1995), (2) the Holland coastal plain, after Jelgersma (1961, 1979), Van de Plassche (1982) and Van de Plassche \& Roep (1989), and (3) the North Sea north of the Frisian Islands, after Behre et al. (1979) and Ludwig et al. $(1979,1981)$; the Belgian curve has been plotted as envelope; the basis for drawing this envelope was discussed by Denys \& Baeteman (1995)

B: flooding history of the Southern Bight based on the RSL curves of Figure 3A (extrapolated for the 9000 and 8500 reconstruction) and the reconstructed pre-transgressional surface (= reconstructed top of the Early Holocene back-barrier deposits, based on the 1:250 000 sheets of the southern North Sea by the Geological Surveys of the UK, the Netherlands and Belgium, and the unpublished map of the base Holocene of the Dutch sector of the North Sea by Kenneth Rijsdijk; solid lines represent the landward boundary of the back-barrier, dashed lines are the inferred barrier coastlines. 
surface, the (decreasing) rate of RSL rise, and the sediment supply.

\section{The morphology of the flooded surface}

This aspect defined the position of sinks and sources. Recent work on the Holocene development of the North Sea coastal plain (Baeteman, 1985; Streif, 1988, 1990; Beets et al., 1992; Flemming \& Davis, 1994; Oost \& De Boer, 1994; Van der Spek, 1996) has shown that the plain was formed by the amalgamation of a large number of relatively small and shallow estuaries, as the rising sea invaded the valleys of the existing drainage pattern and the divides developed into headlands. The landscape prior to flooding, which is now the top of the Pleistocene deposits in the subsurface of the coastal plain, consisted of a drainage pattern of west- and northward-directed streams separated by low divides (Fig. 2A). Except for the Rhine, Meuse and Scheldt rivers, most of these streams provided local drainage.

In contrast to the valleys of these small streams, that of the Rhine/Meuse/Scheldt (the latter two rivers were tributaries of the former during the Early Holocene) was not flooded, as these rivers supplied sufficient sediment to balance the accomodation space created by sea-level rise. Instead, it formed the divide between the Holland tidal basin and a tidal basin at the present site of Zeeland (Fig. 2). As the divides between the valleys were low, they were eventually also flooded, transforming small estuaries into larger tidal basins (in this paper the terms 'estuary', 'tidal basin' and 'back-barrier basin' will be used loosely as synonyms).

\section{The rates of $R S L$ rise and sediment supply}

These two parameters defined whether the coast was receding, stable or prograding. All sediment in the back-barrier basins of Belgium and the Netherlands entered from the North Sea; even sediment supplied by the rivers Rhine, Meuse and Scheldt reached the basins via shoreface and inlets (Beets et al., 1992). As will be discussed below, hardly any of the bed load of the rivers reached the sea directly; most was deposited in the alluvial plain. Only after $4000 \mathrm{BP}$, when the rate of RSL rise at the coast of Holland was reduced to less than $0.2 \mathrm{~cm}$ per year, the main branch of the Rhine could build a small delta. The sediments deposited prior to $6000 \mathrm{BP}$ in that part of the alluvial plain offshore of the present coastline were eroded during recession of the coastline and transported by waves and currents into the tidal basins. Consequently, all were filled from the inlets backwards. Sand to fill the basins was derived from the shoreface adjacent to the inlets and from the ebb-tidal deltas. As long as there was accommodation space in the back-barrier basin, the tidal prism set up tidal currents that brought sand and mud to fill up this space. If insufficient sand was supplied to the shoreface by longshore and cross-shore transport to compensate for this sediment loss, the shoreline was forced to recede.

The size of the back-barrier basin, which is a function of the slope of the pre-transgressional surface, and the rate of RSL rise are the main factors defining the accommodation space. At the rates prior to 7000 $\mathrm{BP}$, sediment supply was insufficient to compensate for the accommodation space created by RSL rise. When the rate of RSL rise dropped to $0.25 \mathrm{~cm}$ per year after about $7000 \mathrm{BP}$ along the Belgian coast (Denys \& Baeteman 1995) and to $0.3 \mathrm{~cm}$ per year after about $6000 \mathrm{BP}$ along the Holland coast (Van de Plassche, 1982), sediment supply could, however, gradually catch up with RSL rise along these westfacing coasts. One after the other, the estuaries were filled, resulting in the closure of associated tidal inlets, stabilization of the adjacent coast, and local barrier progradation. Sediment supply to the northern coast of the Netherlands, on the other hand, was insufficient to fill up the estuaries completely, so that this coastal stretch has remained a slowly receding barrier coast until today.

As will be discussed below, the rate of sediment supply to the back-barrier basins during recession of the coast was high. In the relatively small back-barrier basins of Belgium, intertidal flat and supratidal saltmarsh deposits are therefore common, despite the high rate of RSL rise prior to $7000 \mathrm{BP}$ (Baeteman, 1985, Baeteman et al., 1999). Vegetation levels and thin peat layers are intercalated between the estuarine deposits, indicating that short periods of estuarine sedimentation alternated with even shorter episodes with freshwater conditions and that, locally and temporarily, sediment supply outran the creation of accomodation space by RSL rise (Baeteman et al., 1999). Between about 5500 and $4500 \mathrm{BP}$, when the rate of RSL rise decreased to less than $0.1 \mathrm{~cm}$ per year, and the barrier stabilized, the entire coastal plain changed into a freshwater marsh with peat formation.

The development of the coastal plain of the Netherlands, although similar, differs in a number of respects, such as timing. In the Zeeland area, the early development of the estuary is similar to that of the Belgian coastal plain, but for the absence of peat intercalations. Between 5000 and $4500 \mathrm{BP}$, this coastal plain silted up because of the drop in the rate of RSL rise (Fig. 5), and the barrier stabilized. During the next centuries, the tidal inlets closed and the entire 


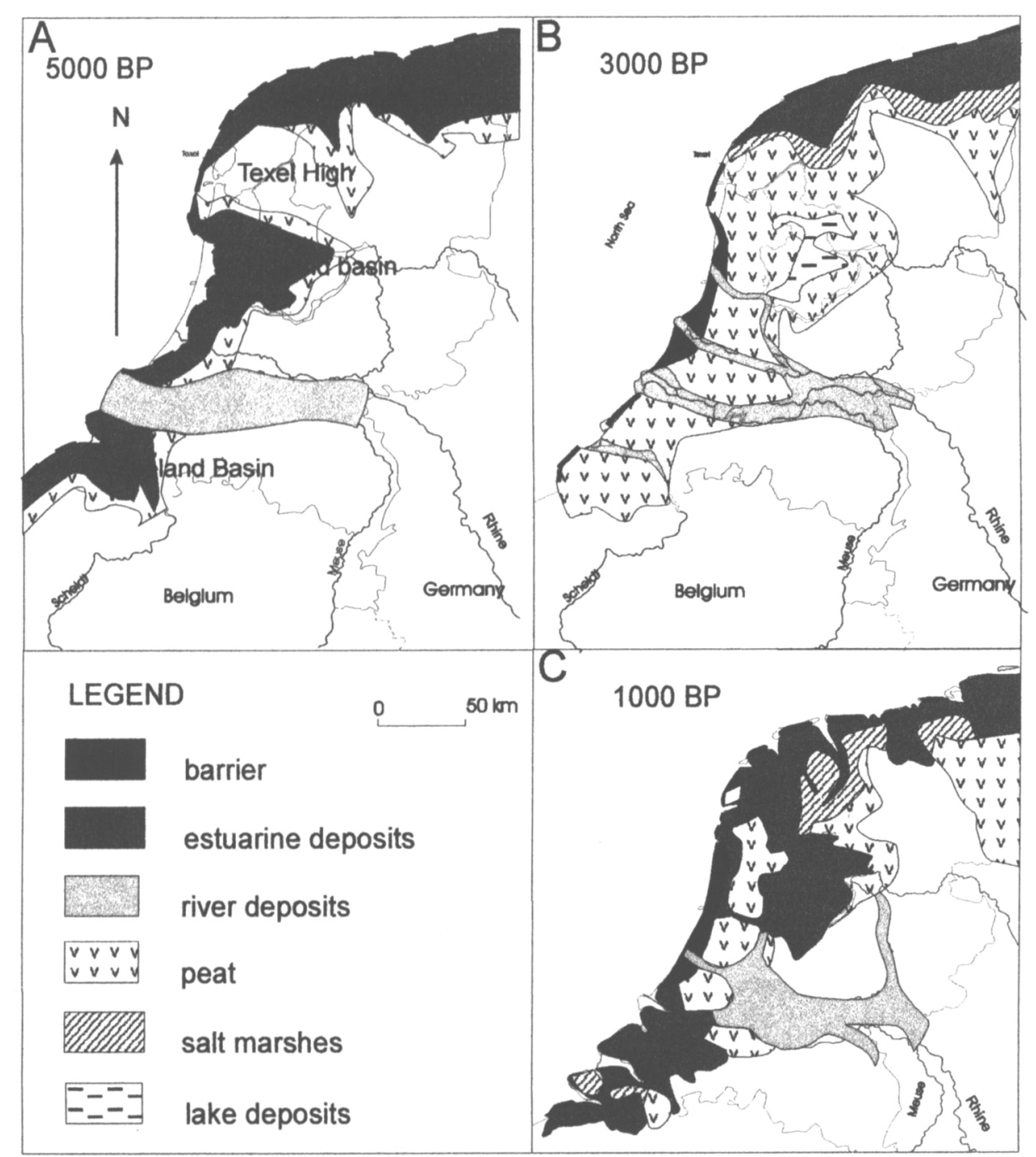

Fig. 5. Simplified paleogeography of the coastal plain of the Netherlands at approx. $5000 \mathrm{BP}$, approx. $3000 \mathrm{BP}$ and approx. $1000 \mathrm{BP}$; modified from Zagwijn (1986).

area changed into a peat marsh (Vos \& Van Heeringen, 1997). This marsh soon developed into an oligotrophic peat cushion, which remained intact until about 2000 BP.

The Zeeland tidal basin is separated from that of Holland (Figs. 2 and 5) by a wide E-W belt of deposits of the Rhine and Meuse rivers, which occupied this location in the central Netherlands between the Weichselian Pleniglacial and about 4000 BP (Törnqvist, 1993; Weerts \& Berendsen, 1995; De Groot \& De Gans, 1996). After 4000 BP, a more northerly branch became the main Rhine discharge (Figs. 5B and 6).

The Holland tidal basin is shallow and narrow at its southern end but deepens and widens towards the north, where it occupies the valley formed by the confluence of a number of local westward-draining streams (Figs. 2A and 5A). In the north, it is bounded by the Texel High, the former divide between the westward and northward drainage. This divide formed a headland throughout most of the Holocene development. In combination with one of the major inlets of the Holland tidal basin, just south of this headland, it became an efficient barrier for longshore transport from the SSW-NNE running Holland coast to the E-W-running Frisian Island coast (Fig. 5A and 5B). The southern part of this basin silted up after $6000 \mathrm{BP}$ and the oldest preserved barrier dates from about 5500 BP (Van der Valk, 1996a). Because of its larger volume, filling of the northern part of this tidal basin took much more time. Here, the barrier shifted landward until about $4400 \mathrm{BP}$ (Beets et al., 1996) and the last tidal inlet closed at about $3300 \mathrm{BP}$ (Roep \& Van Regteren Altena, 1988). In the meantime, the barrier of the Holland tidal basin started to prograde, indicating that the supply of sediment in the south outran the capacity of the northward longshore transport (Fig. 6). Sedimentation in the Holland tidal basin prior to $6000 \mathrm{BP}$ was largely subtidal, as sediment supply lagged behind the creation of accommodation space by RSL rise. Intertidal shoals could only be maintained near the barrier and along the sediment-supplying channels (Van der Spek \& Beets, 1992). When the rate of RSL decreased after 6000 $\mathrm{BP}$, the subtidal areas in the western part of the tidal basin were rapidly filled in. Simultaneously, the distal, 


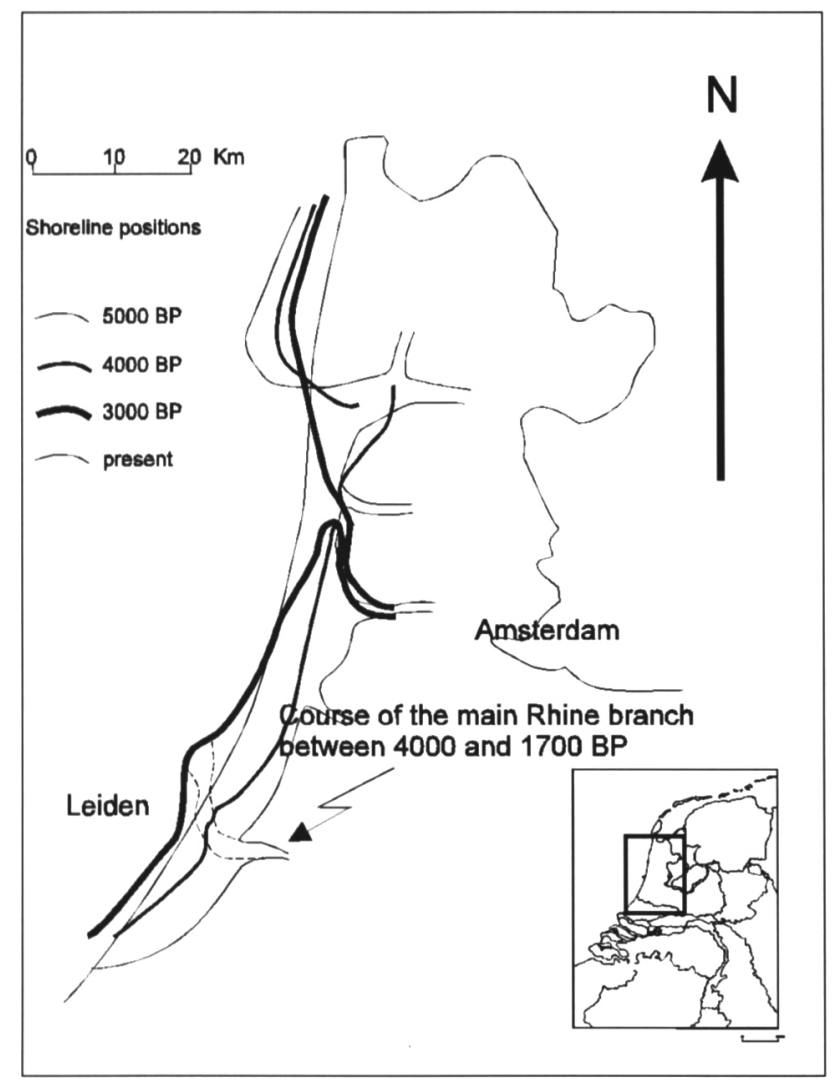

Fig. 6. Coastline positions of the Holland barrier. Timelines of the receding Texel High coast are inferred (after Beets et al., 1992, 1996); see inset for location.

eastern part of the tidal basin became isolated and changed into a major lake, the precursor of the present IJsselmeer (Figs. 1 and 5). After closure of all the tidal inlets, the silted part of the tidal basin changed into a peat swamp (Fig. 5B). Progradation of the barrier coast between the headlands of the alluvial plain in the south and the Texel High in the north continued until after $2000 \mathrm{BP}$. In the Middle Ages, erosion and recession of this part of the coast started (Jelgersma et al., 1970), mainly because of large-scale inlanddirected sanddrift (Van der Valk, 1996b).

The estuaries of the northern Netherlands formed at about $7000 \mathrm{BP}$ when the sea invaded the valleys of two northward discharging local streams in what is now the eastern part of the Dutch Wadden Sea (Fig. 2A). The western part of the Wadden Sea formed much later, around $2000 \mathrm{BP}$, when the Texel High was flooded (Fig. 5C). The main difference in the development of the northern estuaries in comparison to that of the tidal basins of Holland and Zeeland is that they have not been filled, but remained open until today. The prevailing explanation relates this fact to a difference in sediment supply, governed by the position of the outlets of the Rhine and other major rivers along the west-facing coast. As will be discussed below, the supply by the rivers is too small, however, to account for this difference. Alternatively - and more likely - this variability in sediment supply reflects the hydrodynamics and morphology of the Southern Bight.

Throughout most of the Subboreal (5000-2900 BP), the coastal plain of Belgium and the Netherlands was a freshwater marsh with peat cushions spreading all over the landscape (Zagwijn, 1986), except for its northward-draining tidal basin. The only open-marine influence occurred along the outlets of the rivers. The RSL rise continued, however (although at a much slower rate than before), so that this situation gradually changed. Estuarine conditions spread along the river outlets and caused the drainage and resultant collapse of the peat cushions, creating potential and real tidal prisms. In the Middle Ages, this process culminated in extensive flooding of once habitable areas. Flooding of the Belgian coastal plain and the Zeeland area started shortly after $200 \mathrm{AD}$ and transformed the peat areas into wide estuaries with channels, mud flats and salt marshes. Most of the interfluve areas between the channels in the Zeeland area were silted up to high-tide level by $1000 \mathrm{BP}$, and people started to construct dikes to protect these newly formed islands. In the northern and northwestern part of the Netherlands, the Texel High was flooded and the Wadden Sea became connected to the large lake in the centre of the country (Fig. 5C). At the same time, extensive peat areas behind the coastal barrier of Holland changed into tidal mud flats. By then, political organization was such that protective measures could be taken to protect the people and their land.

\section{Sediment volume in the coastal plain of the Netherlands}

We have quantified the amount of sand, mud and peat in the subsurface of the Dutch coastal plain by subdividing the outcrop area into 16 sub-areas, for each of which the amount of sand, mud and peat was calculated on the basis of one or more profiles (cf. Van der Spek, 1995). It was possible, by using different combinations of profiles, to constrain the error range to $\pm 15 \%$, which holds for all the figures given below.

The total amount of sediment stored in the Holocene coastal plain of the Netherlands is about $226 \cdot 10^{9}$ $\mathrm{m}^{3}$, almost $70 \%$ of which is sand (Table 1). The amount of peat is small, as much has either disappeared by erosion, oxidation and exploitation, or has been strongly reduced in volume because of compaction. The Wadden Sea tidal basin contains slightly more sediment than the Holland and Zeeland (Table 
Table 1. Total sediment volume of the Holocene deposits in the coastal plain of the Netherlands.

\begin{tabular}{lcc}
\hline material & volume & $\begin{array}{l}\text { relative } \\
\text { percentage }\end{array}$ \\
\hline sand & $153 \cdot 10^{9} \mathrm{~m}^{3}$ & $68 \%$ \\
mud & $62 \cdot 10^{9} \mathrm{~m}^{3}$ & $27 \%$ \\
peat & $11 \cdot 10^{9} \mathrm{~m}^{3}$ & $5 \%$ \\
total & $226 \cdot 10^{9} \mathrm{~m}^{3}$ & $100 \%$ \\
\hline
\end{tabular}

Table 2. Sediment volumes (in $10^{9} \mathrm{~m}^{3}$ ) in the three main tidal basins of the Netherlands.

\begin{tabular}{lrrrrr}
\hline area & sand & mud & peat & total & percentage \\
\hline Wadden Sea & 64 & 19 & 3 & 86 & $38 \%$ \\
Holland & 44 & 27 & 4 & 75 & $33 \%$ \\
Zeeland & 45 & 16 & 4 & 65 & $29 \%$ \\
total & 153 & 62 & 11 & 226 & $100 \%$ \\
\hline
\end{tabular}

2) basins. When calculated over the length of the shoreline (Table 3), however, sediment supply to the Holland and Zeeland basins was considerably higher, particularly when considering that the Wadden Sea basin stayed open and received sediment throughout the Holocene, whereas the others were closed during a large part of the Subboreal and Subatlantic.

We tried to quantify the variations in sediment supply through time, but because of insufficient ${ }^{14} \mathrm{C}$ data to construct isochrons in the sediment succession, we could make only a rough guess based on the assumption that sedimentation in the back-barrier basin would follow RSL rise. This assumption is justified for most of the period after $5000 \mathrm{BP}$ when the rate of RSL rise was less than $3 \mathrm{~cm}$ per year. Prior to 5000 $\mathrm{BP}$, the sedimentation rate in the Holland tidal basin lagged behind RSL rise, requiring a correction which we based on the existing ${ }^{14} \mathrm{C}$ record (see for details Van der Spek, 1995). As expected, sediment supply was high during the Atlantic, and decreased during the Subboreal and during the Subatlantic (Table 4). This decrease primarily reflects the decrease in the rate at which new accomodation space was created, governed in turn by falling rates of RSL rise.

Not all sediment accumulation is related to the creation of accommodation space in the back-barrier basins, however, as reflected by the Subboreal progradation of the Holland coast (Fig. 6), which involved $9-10 \cdot 10^{9} \mathrm{~m}^{3}$ of sand (Beets et al., 1992). Nevertheless, our numbers show a strong overall decrease in time, to almost zero at present, of the sediment-supply rate to the Dutch coastal plain. In order to explain this decrease, we need to investigate the sediment sources.
Table 3. Sediment volumes of the Holocene deposits in the coastal plains of the Wadden Sea, Holland and Zeeland areas (in $10^{3} \mathrm{~m}^{3}$ per meter coastline).

\begin{tabular}{lccccc}
\hline area & $\begin{array}{l}\text { length of } \\
\text { the coast- } \\
\text { line }(\mathrm{km})\end{array}$ & sand & mud & peat & $\begin{array}{l}\text { total of } \\
\text { clastics }\end{array}$ \\
\hline Wadden Sea & $161 \mathrm{~km}$ & 402 & 119 & 17 & 521 \\
Holland & $100 \mathrm{~km}$ & 440 & 269 & 43 & 709 \\
Zeeland & $96 \mathrm{~km}$ & 472 & 162 & 38 & 634 \\
\hline
\end{tabular}

Table 4. Accumulated sediment volumes and rates of accumulation per time interval.

\begin{tabular}{llll}
\hline $\begin{array}{l}\text { time } \\
\text { interval }\end{array}$ & $\begin{array}{l}\text { age } \\
(14 \mathrm{C} \\
\text { years BP })\end{array}$ & $\begin{array}{l}\text { volume } \\
\left(10^{9} \mathrm{~m}^{3}\right)\end{array}$ & $\begin{array}{l}\text { accumulation } \\
\text { rate } \\
\left(10^{6} \mathrm{~m}^{3} \cdot \mathrm{a}^{1}\right)\end{array}$ \\
\hline Atlantic & $8000-5000$ & $136(60 \%)$ & 41 \\
Subboreal & $5000-2900$ & $67(30 \%)$ & 27 \\
Subatlantic & 2900 -recent & $23(10 \%)$ & 7 \\
\hline
\end{tabular}

\section{Sediment sources}

All clastic sediments in the coastal plain of Belgium and the Netherlands derive from only three sources: an alluvial source (the Rhine, Meuse and Scheldt rivers), the Pleistocene basement eroded during recession of the shoreline, and the North Sea (Van Straaten, 1965). The individual contribution of the different sources is difficult to quantify on the basis of grainsize and mineral composition as the Pleistocene basement of the North Sea in front of the coasts of Belgium, Zeeland and Holland consists of low-stand Rhine deposits or coversands derived from the latter. As shown by Eisma (1968), the heavy mineral association of the coastal sands along the Holland coast has a strong Rhine signature, but whether the sands are derived by longshore drift from the outlets of the river or by cross-shore transport from reworked Pleistocene Rhine deposits on the North Sea floor cannot be established.

At present, the rivers bring little or no sand to their outlets. The mean discharge of the Rhine at the Dutch/German border is $2300 \mathrm{~m}^{3} \cdot \mathrm{s}^{-1}$, stemming from both rain and snow. Maximum discharges are up to $12,000 \mathrm{~m}^{3} \cdot \mathrm{s}^{-1}$. It is estimated that the total amount of bed and suspended load passing the German/ Dutch border is in the order of $0.5 \cdot 10^{6} \mathrm{~m}^{3} \cdot \mathrm{a}^{-1}$ and $2 \cdot 10^{6}$ $\mathrm{m}^{3} \cdot \mathrm{a}^{-1}$, respectively, based on measurements of sediment transport carried out over the last fifteen years in the main branch of the Rhine (Ten Brinke, 1998). Most of the supplied bedload is dredged, to keep the river navigable. The mean discharge of the Meuse north of the town of Maastricht near the Belgian/ 
Dutch border is $230 \mathrm{~m}^{3} \cdot \mathrm{s}^{-1}$, and that of the river Scheldt is even less, so that the contribution of these rivers to the present-day sediment supply is negligible. We postulate that low fluvial sediment supply by the rivers characterized much of the Holocene, based on the amount of bed load deposited by the main branch of the river Rhine in the interval between approx. $4000 \mathrm{BP}$ (corresponding with approx. $2500 \mathrm{BC}$ : Stuiver \& Reimer, 1993) and 1700 BP (200 AD), and the evolution of channel morphology during the Holocene (Törnqvist, 1993; Törnqvist et al. 1993; De Groot \& De Gans, 1996). No Holocene delta deposits have been preserved, except for a small protrusion in the otherwise smooth barrier and swale morphology of the prograding barrier sequence around the outlet of the largely Subboreal Rhine branch near the town of Leiden (Figs. 5B and 6). Over a period of about 2700 year, this was the main branch of the Rhine (Törnqvist, 1993; De Groot \& De Gans, 1996).

During this period, the river built an about $2-\mathrm{km}$ wide, $10-\mathrm{m}$ deep and $70-\mathrm{km}$ long sand-rich meander belt, which contains about $1.4 \cdot 10^{9} \mathrm{~m}^{3}$ of sand. By extrapolation of the barrier morphology offshore, a modest delta can be reconstructed which contained about $0.5 \cdot 10^{9} \mathrm{~m}^{3}$ of sand if we place its base at a mean depth of $-15 \mathrm{~m}$ NAP (Beets et al., 1992). The reconstructed delta formed part of the prograding Holland barrier coast. Model calculations by Zitman (in Beets et al., 1992) show that between approx. 5000 and $3000 \mathrm{BP}$ about $10^{9} \mathrm{~m}^{3}$ of sand was supplied to this coast by northward-directed longshore transport. As the delta was incorporated in this longshore transport cell, it changed the gradients in longshore transport so that river sand removed by longshore transport towards the north was replenished from the south. Only after abandonment of the channel, longshore transport smoothed the coast: at present, the protrusion can only be recognized in the fossil barrier and swale morphology. Reconstruction of the delta gives us therefore a rough estimate of the sand transport by the main Rhine branch between approx. 2500 BC to 200 AD: $\pm 1.9 \cdot 10^{9} \mathrm{~m}^{3}$ in about 2700 calender years, which is approx. $0.7 \cdot 10^{6} \mathrm{~m}^{3}$ annually.

Sediment supply by the rivers during the Holocene depends on the discharge (which is a function of climate and vegetation), on the channel gradient and on the erodability of the rocks in the catchment area. Holocene climatic variations (Lamb, 1982; Bond et al., 1997) certainly influenced the rainfall, as is evident from, for instance, lake levels in the Alps (Joos, 1982) and changes in the vegetation in peat bogs (Van Geel et al,. 1996). Consequently, discharge of the rivers may have been greater in the past. On the other hand, the catchment areas were characterized by a dense vegetation reducing the runoff and inhibiting erosion. None of these factors can be quantified as yet, but, as the life time of the Rhine branch discussed above is about twice the duration of the cycles of climatic fluctuations as established by Bond et al. (1997), we assume that the variations in sediment transport because of variations in discharge are incorporated in our calculation of the total sediment output.

The decreasing gradient due to base-level rise (= RSL rise) finds expression in the succession of channel morphologies in the alluvial and coastal plain (Törnqvist, 1993; Weerts \& Berendsen, 1995; De Groot \& De Gans, 1996; Makaske, 1998). The Holocene succession of channel types consists of meandering channels in the lower part overlain by anastomosing channels which pass upwards in the present-day channel morphology. The transition from meandering to anastomosing in the area between Rotterdam and Utrecht (Fig. 1) took place at about $7000 \mathrm{BP}$ and is the result of the rapidly rising baselevel, which forced the river to dump all or a large part of its bedload in the alluvial plain to keep pace with RSL rise. Törnquist et al.(1993) showed that the anastomising channels graded into the meandering type upstream, indicating that the two different channel types are not the result of changes in discharge and sediment transport. This lateral change in channel morphology and overall alluvial facies also suggest that the meandering channels in the basal part of the Holocene succession in the present coastal plain were once connected to anastomosing channels active at a much lower base level when the coast was situated in the present North Sea. Beets et al. (1992) assumed that the sand deposited in those channels was incorporated in the receding shoreline and eventually redistributed by longshore transport.

The above considerations give little support to major differences in discharge and sediment transport of the rivers during the Holocene, and support our view that discharge and sediment load have not changed considerably since the Early Atlantic. For this reason we consider the alluvial contribution to the Holocene sand budget to be in the order of $10^{6} \mathrm{~m}^{3}$ per year. The present annual discharge of suspended mud by Rhine and Meuse was estimated by Terwindt (1977) at $1.5 \cdot 10^{6}$ metric ton, which is comparable to the sand supply. Even if we assume that all mud and sand supplied by the rivers during the Holocene was deposited in the coastal plain, the contribution of the rivers hardly surpasses $10 \%$ of the $226 \cdot 10^{9} \mathrm{~m}^{3}$ of sediment stored in the coastal-plain succession of the Netherlands. Hence, $90 \%$ of all sediment stored in the 
coastal plain derived from the two other sources, i.e. the Pleistocene basement and the North Sea.

There are two possibilities to distinguish roughly between the contributions of these two sources. The first is by using the sediment budget of the prograding Holland barrier sequence; the second is by comparing the sediment supply to the north-facing Wadden Sea back-barrier basins to that of the west-facing Holland basin. One should realize that both represent very rough estimates and are only meant to give some approximation for the contribution of the various sources to the sand budget. As outlined by Beets et al. (1992), about $70 \%$ of the $9-10 \cdot 10^{9} \mathrm{~m}^{3}$ of sand stored in the prograding Holland barrier sequence could be accounted for by the erosion of headlands (approx. $\left.3 \cdot 10^{9} \mathrm{~m}^{3}\right)$, by the small Rhine delta discussed above $\left(0.5 \cdot 10^{9} \mathrm{~m}^{3}\right)$ and by the incorporation of ebb-tidal deltas of former inlets $\left(3.5 \cdot 10^{9} \mathrm{~m}^{3}\right)$. They assume that the remaining " 3 billion $\mathrm{m}^{3}$ must have come from reworking of Pleistocene sands in the southern North Sea and from landward transport by shore-normal processes". Progradation took place between about 5000 (corresponding with approx. 5700 calender years BP) and $2000 \mathrm{BP}$ over a coastline of about 80 $\mathrm{km}$ long, which gives a sediment supply from this North Sea source of about $10 \mathrm{~m}^{3} \cdot \mathrm{m}^{-1} \cdot \mathrm{a}^{-1}$. This is a minimum value as most of the mud from this source was not incorporated in the barrier sequence.

Provided that all sediment of the Wadden Sea tidal basin and barrier was supplied by erosion of the basement during recession of the barrier, and assuming that sediment supply by erosion during recession of the barrier is independent of the orientation of the coastline and was roughly the same per meter coastline for the Wadden Sea tidal basin and the Holland tidal basin, it is possible to estimate the difference in sediment supply per time unit, which gives us the supply rate of the North Sea source. The total amount of sand and mud in the Wadden Sea tidal basins is $521 \cdot 10^{3} \mathrm{~m}^{3}$ per meter coastline (Table 3 ). When progradation of the Holland coast ended at about $2000 \mathrm{BP}$, and no sediment was added anymore to the Holland coast and basin, about $90 \%$ of $521 \cdot 10^{3}$ $\mathrm{m}^{3} \cdot \mathrm{m}^{-1}$ coastline $\left(=469 \cdot 10^{3} \mathrm{~m}^{3} \cdot \mathrm{m}^{-1}\right)$ was present in the Wadden Sea tidal basin; the clastic sediments present in the Holland tidal basin and barrier amount to $709 \cdot 10^{3} \mathrm{~m}^{3} \cdot \mathrm{m}^{-1}$ (Table 3). Provided that both areas received the same amount of sediment by erosion during recession of the coast, the North Sea source supplied $709 \cdot 10^{3} \mathrm{~m}^{3} \cdot \mathrm{m}^{-1}-469 \cdot 10^{3} \mathrm{~m}^{3} \cdot \mathrm{m}^{-1}=240 \cdot 10^{3}$ $\mathrm{m}^{3} \cdot \mathrm{m}^{-1}$ to the Holland tidal basin. If we assume that this North Sea source operated from about 8000 BP (approx. 8700 calender years BP) onwards and supplied sediment to the Holland coast until $2000 \mathrm{BP}$, the supply rate would be in the order of an average of $30-40 \mathrm{~m}^{3} \cdot \mathrm{m}^{-1} \cdot \mathrm{a}^{-1}$. As discussed earlier, the sediments deposited by the rivers in the alluvial plain are reworked by coastal recession and are therefore not treated as an independent source in these calculations.

The calculated rate of sediment supply by the North Sea source to the west-facing coasts during the Holocene is of the same magnitude as the modern northward-directed longshore transport at the $-20-\mathrm{m}$ depth contour along the coast of Holland, which amounts to $10-40 \mathrm{~m}^{3} \cdot \mathrm{m}^{-1} \cdot \mathrm{a}^{-1}$ (Van Rijn, 1995). According to Van Rijn (1995), hardly any of this sand reaches the present coastline. Modelling of the sediment transport in the North Sea at the present and lower sea-level stands by Gerritsen \& Berentsen (1998) has shown that there is no basic difference between the pattern of erosion and deposition at present and in the past, suggesting that changes in the coastline configuration are responsible for this change in sediment dispersal.

The most important changes in coastal morphology were the transition from a more or less open coast to a closed coast in the Late Atlantic and Early Subboreal, and the gradual steepening of the west-facing shoreface of Holland in the Subatlantic, in particular during and after the Middle Ages (Van der Valk, 1996a). During the Atlantic, the sediment flux probably had an important east-west component, from the Southern Bight into the estuaries, as the back-barrier basins provided accomodation space and tidal prism. Those of Belgium were the first to silt up because of their size and the relatively early decrease of the rate of RSL rise. Given the fact that there was little or no progradation of the coastlines of Belgium and Zeeland after their closure, it is tempting to assume that the strong tidal currents on the coast-parallel Flemish and Zeeland Ridges prohibited cross-shore transport, but that part of the northward flux of sand was bent towards the Holland coast. The onset of progradation of the coast of Holland in the late Atlantic (approx. $5500 \mathrm{BP}$ ) marks the beginning of the change from an open coast with a large number of inlets to the closed coast of today (Pons et al., 1963; Beets et al., 1992). Ebb-tidal deltas of degrading and closed inlets, modified by waves and tidal currents into shoreface-connected ridges, could have been the stepping stone for sand from the North Sea to enter the upper shoreface, where waves could transport it shorewards. Incorporation of these modified ebb-tidal deltas into the prograding barrier sequence during the course of the Subboreal and Early Subatlantic would have cut off this cross-shore pathway for the Southern Bight sand flux. This could eventually have led to shoreface 
erosion in historical times (Jelgersma et al., 1970; Van derValk, 1996a,b).

In contrast to the SE-NW-running shoreline of Holland, no such extra sediment source was available to the northern Wadden Sea tidal basin. All the sand of this estuary came from erosion of the Pleistocene deposits during ongoing barrier recession. The Texel High formed a headland that remained an obstacle for longshore transport of sand from the Holland coast to the Wadden Sea coast almost up to Medieval times.

\section{Summary and conclusions}

The following seven main conclusions can be drawn.

Rapid flooding of the southern part of the North Sea, reflecting high rates of RSL rise, took place between 9000 and 8000 BP. Differences in the rate of RSL rise are due to differential glacio- and hydro-isostatic movement. Ages of estuarine sediments indicate that the sea invaded the depressions in the Belgian coastal plain around $8500 \mathrm{BP}$ and those of the Netherlands at about $8000 \mathrm{BP}$.

The morphology of the pre-transgressional surface defined the initial position of estuaries and headlands.

The balance between the creation of accommodation space and the sediment supply defined whether the early barriers receded or stabilized. In a tidedominated back-barrier basin with shoals and channels, the tidal prism, and consequently the transport capacity is directly affected by changes in accommodation space. As all or most sand brought into the back-barrier basin derived from the fronting barrier, an increase in accommodation space meant erosion and recession of the barrier.

The Belgian barrier and back-barrier basin stabilized after $7000 \mathrm{BP}$ when the local rate of RSL rise had fallen to $0.25 \mathrm{~cm} \cdot \mathrm{a}^{-1}$; between 5500 and $4500 \mathrm{BP}$, it changed into a freshwater marsh with peat accumulation. The Zeeland and Holland barrier systems followed slightly later; the oldest barrier in the southern part of the Holland coasts dates from 5500, whereas the last tidal inlet closed at about 3500 BP. Stabilization of the barrier and silting of the tidal basins occurred because of the decreasing rate of RSL rise, causing sediment supply to surpass the creation of accommodation space. In contrast to these barrier systems, the Wadden Sea in the northern part of the Netherlands has stayed open until today, indicating that sediment supply has been insufficient to fill up the tidal basin.

Between about 5000 and $2000 \mathrm{BP}$, the central part of the coast of Holland prograded almost $10 \mathrm{~km}$. Sand for the progradation was provided by the reworking of ebb-tidal deltas of former inlets, by the erosion of the adjacent headlands, by shore-normal transport from the North Sea, and by a small alluvial source.

A total of $226 \cdot 10^{9} \mathrm{~m}^{3}( \pm 15 \%)$ of sediment is stored in the Holocene coastal plain of the Netherlands. It is estimated that about $60 \%$ was deposited prior to $5000 \mathrm{BP}, 30 \%$ between 5000 and $2900 \mathrm{BP}$ (Subboreal) and $10 \%$ since then. In other words, sediment supply decreases with the decreasing sea-level rise. This reflects, among others, the decrease in accommodation space.

Although we have little control on the amount of sediment supplied by the Rhine and Meuse rivers, the best calculations available to date show that the contribution of the rivers to the total amount of sediment of the coastal plain is of the order of $10 \%$. This implies that $90 \%$ of the sediment derived from erosion of Pleistocene deposits during recession of the barriers and from the North Sea by tide-induced shorenormal currents. Most sediment comes from the first source. Modelling of tide-induced sediment transport in the southern North Sea at sea-levels of $0,-5$ and $-15 \mathrm{~m}$ by Gerritsen and Berentsen (1998) shows that eroded sediment in the southern part of the Southern Bight has been transported northward throughout most of the Holocene. We suggest that part of this sediment flux found its way into the west-facing backbarriers basins of Belgium, Zeeland and Holland, and is responsible for the early silting up of these basins. Simple calculations, based on the sand budget of the prograding barrier of Holland, and on a comparison of the tidal basins of Holland and the Wadden Sea suggests that the North Sea source supplied 10-40 $\mathrm{m}^{3} \cdot \mathrm{m}^{-1} \cdot \mathrm{a}^{-1}$ to the Holland coast. Modelling shows that sand from this latter source does not reach the tidal basins of the Wadden Sea coast, which might explain why these tidal basins still exist.

\section{Acknowledgements}

Kenneth Rijsdijk was so kind to let us use his unpublished data on RSL rise in the Southern Bight and his unpublished base-Holocene map of the Dutch sector of the North Sea; both were used for the paleogeographic reconstructions of Figure 4. We thank the two referees, Dr. Rik Donselaar and Dr. Sytze van Heteren, for their constructive criticism. In particular the numerous remarks by Dr. Van Heteren have improved this paper considerably. Special thanks are furthermore due to Dr. Bert van der Valk, who assisted the authors at an early stage, and to all the other participants of the Coastal Genesis Project for the discussions, help and ideas without which this paper could not have been written. 


\section{References}

Austin, R.M., 199. Modelling Holocene tides on the NW European continental shelf. Terra Nova 3: 276-288.

Baeteman, C., 1985. Development and evolution of sedimentary environments during the Holocene in the western coastal plain of Belgium - Eiszeitalter und Gegenwart 35:23-32.

Baeteman, C., D.J.Beets \& Van Strydonck, M., 1999. Tidal crevasse splays as the cause of rapid changes in the rate of aggradation in the Holocene tidal deposits of the Belgian coastal plain. Quaternary International 56: 3-13.

Beets, D.J., Van der Valk, L. \& Stive, M.J.F., 1992. Holocene evolution of the coast of Holland. Marine Geology 103: 423-443.

Beets, D.J., Roep, Th.B. \& Westerhoff, W.E., 1996. The Bergen inlet: closing history and related barrier progradation. Mededelingen Rijks Geologische Dienst 57: 97-133.

Behre, K.-E., Menke, B. \& Streif, H., 1979. The Quaternary geological development of the German part of the North Sea. In: Oele, E., Schüttenhelm, R.T.E.. \& Wiggers, A.J. (eds.): The Quaternary history of the North Sea. Acta Universitatis Upsaliensis, Symposia Universitatis Upsaliensis Annum Quingentesimum Celebrantis (Uppsala) 2: 85-115.

Berné, S., Trentesaux, A., Stolk, A., Missiaen, T. \& De Batist, M., 1994. Architecture and long term evolution of a tidal sandbank: the Middelkerke Bank (southern North Sea). Marine Geology 121: 57-72.

Bond, G., Showers, W., Cheseby, M., Lotti, R., Almasi, P., DeMenocai, P., Priori, P., Cullen, H. Hajdas, I. \& Bonani, G., 1997. A pervasive millennial-scale cycle in North Atlantic Holocene and Glacial Climates. Science 278: 1257-1266.

Collins, M.B., Shimwell, S.J., Gao, S., Powell, H., Hewitson, C. \& Taylor, J.A., 1995. Water and sediment movement in the vicinity of linear sandbanks: the Norfolk Banks, southern North Sea. Marine Geology 123: 125-142.

De Gans, W. \& Van Gijssel, K., 1996. The late Weichselian morphology of the Netherlands and its influence on the Holocene coastal development. Mededelingen Rijks Geologische Dienst 57: 11-25.

De Groot, Th.A.M. \& De Gans, W., 1996. Facies variations and sea-level-rise response in the lowermost Rhine/Meuse area during the last 15000 years (the Netherlands). Mededelingen Rijks Geologische Dienst 57: 229-250.

Denys, L. \& Baeteman, C., 1995. Holocene evolution of relative sea-level and local mean high water spring tides in Belgium: a first assessment. Marine Geology 124: 1-19.

Dronkers, J., 1986. Tidal asymmetry and estuarine morphology. Netherlands Journal of Sea Research 20: 117-131.

Eisma, D., 1968. Composition, origin and distribution of Dutch coastal sands between Hoek van Holland and the Island of Vlieland. Netherlands Journal of Sea Research 4: 123-267.

Flemming, B.W. \& Davis Jr., R.A., 1994. Holocene evolution, morphodynamics and sedimentology of the Spiekeroog barrier island system (southern North Sea.- Senckenbergiana Maritima 24: 117-155.

Gerritsen, H. \& Berentsen, C.W.J., 1998. A modelling study of tidally induced equilibrium sand balances in the North Sea during the Holocene. Continental Shelf Research 18: 151-200.

Houbolt, J.J.H.C., 1968. Recent sediments in the Southern Bight of the North Sea. Geologie en Mijnbouw 47: 245-273.

Houthuys, R., De Moor, G. \& Sommé, J., 1993. The shaping of the French-Belgian North Sea coast throughout recent geology and history. In: Magoon, O.T. et al. (eds.): Coastlines of the southern North Sea. American Society of Civil Engineers: 27-41.

Jelgersma, S., 1961. Holocene sea level changes in the Netherlands. Mededelingen Geologische Stichting CVI 7: 1-100.
Jelgersma, S., 1979. Sea level changes in the North Sea Basin. In: Oele, E., Schüttenhelm, R.T.E. \& Wiggers, A.J. (eds.): The Quaternary history of the North Sea. Acta Universitatis Upsaliensis, Symposia Universitatis Upsaliensis Annum Quingentesimum Celebrantis (Uppsala) 2: 233-248.

Jelgersma, S., De Jong, J., Zagwijn, W.H. \& Van Regteren Altena, J.F., 1970. The coastal dunes of the western Netherlands: geology, vegetational history and archeology. Mededelingen Rijks Geologische Dienst 21: 93-167.

Johnson, M.A., Kenyon, N.H., Belderson, R.H. \& Stride, A.H., 1982. Sand transport. In: Stride, A.H. (ed.): Offshore tidal sands: processes and deposits. Chapman \& Hall (London): 5894.

Joos, M. 1982 Swiss Midland-lakes and climatic changes. In: Harding, A.F. (ed.): Climatic change in later prehistory. Edinburgh University Press: 44-52.

Kenyon, N.H., Belderson, R.H. Stride, A.H. \& Johnson, M.A., 1981. Offshore tidal sand-banks as indicators of net sand transport as potential deposits. International Association of Sedimentologists Special Publication 5: 257-268.

Kroon, A., 1990. Three dimensional morphological changes of a nearshore bar system along the Dutch coast near Egmond aan Zee. In: Proceedings of the Skagen Symposium. Journal of Coastal Research, Special Issue 9: 430-451.

Lamb, H.H., 1982. Reconstruction of the course of postglacial climate over the world. In: Harding, A.F. (ed.): Climatic change in later prehistory. Edinburgh University Press: 11-33.

Ludwig, G., Müller, H. \& Streif, H., 1979. Neuere Daten zum holozänen Meeresspiegelanstieg im Bereich der Deutschen Bucht. Geologisches Jahrbuch 32D: 3-22.

Ludwig, G., Müller H. \& Streif, H., 1981. New dates on Holocene sea-level changes in the German Bight. International Association of Sedimentologists Special Publication 5: 211-219.

Makaske, B., 1998 Anastomosing rivers. Ph.D. thesis University of Utrecht: $285 \mathrm{pp}$.

McCave, I.N., 1971. Sand waves in the North Sea off the coast of Holland. Marine Geology 10: 199-225.

Oost, A.P., 1995. Sedimentological implications of morphodynamic changes in the ebb-tidal delta, the inlet, and the drainage basin of the Zoutkamperlaag tidal inlet (Dutch Wadden Sea), induced by a sudden decrease in tidal prism. International Association of Sedimentologists Special Publication 24: 101-119.

Oost, A.P. \& De Boer, P.L., 1994. Sedimentology and development of barrier islands, ebb-tidal deltas, inlets and backbarrier areas of the Dutch Wadden Sea - Senckenbergiana Maritima 24: 65-115.

Pons, L.J., Jelgersma, S., Wiggers, A.J. \& De Jong, J.D., 1963. Evolution of The Netherlands coastal area during the Holocene. Verhandelingen Koninklijk Nederlands Geologisch Mijnbouwkundig Genootsschap 21(2): 197-208.

Roep, Th.B. \& Van Regteren Altena, J.A., 1988. Palaeotidal levels in tidal sediments (3800-3635 BP); compaction, sea-level rise and human occupation (3275-2620 BP) at Bovenkarspel, NW Netherlands. In: De Boer, P.L. et al.(eds.): Tide-influenced sedimentary environments and facies. Reidel Publishing Company (Dordrecht): 215-231.

Sha, L.P., 1989 Cyclic morphological changes of the ebb-tidal delta, Texel Inlet, The Netherlands. Geologie en Mijnbouw 68: 35-48.

Streif, H., 1988. Barrier islands, tidal flats, and coastal marshes resulting from a relative rise of sea level in East Frisia on the German North Sea coast. In: Van der Linden, W.J.M. et al. (eds.): Coastal lowlands, Proceedings of a Symposium of the Royal Geological andMining Society of the Netherlands (KNGMG). Kluwer (Dordrecht): 213-225.

Streif, H, 1990. Das ostfriesische Küstengebiet. Sleswig Geologi- 
sche Führer 57 (Borntraeger, Berlin): 376 pp.

Stuiver, M. \& Reimer, P.J., 1993. Extended ${ }^{14} \mathrm{C}$ data base and revised CALIB 3.0 14C age calibration program. In: Stuiver, M., Long, A. \& Kra, R.S. (eds.): Calibration 1993. Radiocarbon 35: 215-230.

Ten Brinke, W.B.M., 1998. The importance of large-magnitude floods for long-term sediment transport and morphodynamics in the Dutch Rhine river system. In: Kroon, A. \& Ruessink, B.G. (eds.): Geographical developments in coastal morphodynamics a tribute to Joost Terwindt. Faculteit Ruimtelijke Wetenschappen, University of Utrecht: 59-83.

Terwindt, J.H.J., 1977. Mud in the Dutch delta area. Geologie en Mijnbouw 56: 203-210.

Törnqvist, T.E., 1993. Holocene alternation of meandering and anastomosing fluvial systems in the Rhine-Meuse delta (CentralNetherlands) controlled by sea-level rise and subsoil erodibility. Journal of Sedimentary Petrology 63: 683-693.

Törnqvist, T.E., Van Ree, M.H.M. \& Faessen, E.H.J.L., 1993. Longitudinal facies architectural changes of a Middle Holocene anastomosing distributary system (Rhine-Meuse delta, central Netherlands). Sedimentary Geology 85: 203-219.

Van de Plassche, O., 1982. Sea-level change and water-level movements in the Netherlands during the Holocene. Mededelingen Rijks Geologische Dienst 36: 1-93.

Van de Plassche, O. \& Roep, Th.B., 1989. Sea-level changes in the Netherlands during the last 6500 years: basal peat vs. coastal barrier data. In: Scott, D.B., Pirazolli, P.A. \& Honig, C.A. (eds.): Late Quaternary sea-level correlation and applications. NATO ASI Series, C256 (Kluwer, Dordrecht): 41-56.

Van der Spek, A.J.F., 1995. Holocene sediment influxes in the coastal zone of the Netherlands and the North Sea as a function of sea-level rise and wave- and tide-induced sand transport. Internal Report Geological Survey of the Netherlands (Haarlem) 90.017: $10 \mathrm{pp}$.

Van der Spek, A.J.F., 1996. Holocene depositional sequences in the Dutch Wadden Sea south of the island of Ameland. Mededelingen Rijks Geologische Dienst 57: 41-69.
Van der Spek, A.J.F. \& Beets, D.J., 1992. Mid-Holocene evolution of a tidal basin in the western Netherlands: a model for future changes in the northern Netherlands under conditions of accelerated sea-level rise? Sedimentary Geology 80: 185-197.

Van der Valk, L., 1996a. Geology and sedimentology of Late Atlantic, wave-dominated deposits near The Hague (South-Holland, the Netherlands): a reconstruction of an early prograding coastal sequence. Mededelingen Rijks Geologische Dienst 57: 201-228.

Van der Valk, L., 1996b. Coastal barrier deposits in the central Dutch coastal plain. Mededelingen Rijks Geologisch Dienst 57: 133-201.

Van Geel, B., Buurman, J. \& Waterbolk, H.T., 1996. Archaeological and palaeoecological indications of an abrupt climate change in The Netherlands, and evidence for climatological teleconnections around 2650 BP. Journal of Quaternary Science 11: 451460 .

Van Rijn, L.C., 1995. Sand budget and coastline changes of the central coast of Holland between Den Helder and Hoek of Holland, period 1964-20450. Delft Hydraulics Report H2129: 126 pp.

Van Straaten, L.M.J.U., 1961. Directional effects of winds, waves and currents along the Dutch North Sea coast. Geologie en Mijnbouw 40: 333-346 + 363-391.

Van Straaten, L.M.J.U., 1965. Coastal barrier deposits in South and North Holland - in particular in the area around Scheveningen and IJmuiden. Mededelingen Geologische Stichting, Nieuwe Serie 17: 41-75.

Vos, P.C. \& Van Heeringen, R.M., 1997. Holocene geology and occupation history of the Province of Zeeland. Mededelingen Rijks Geologische Dienst 59: 5-109.

Weerts, H.J.T \& Berendsen, H.J.A., 1995. Late Weichselian and Holocene fluvial palaeogeography of the southern Rhine-Meuse delta, The Netherlands. Geologie en Mijnbouw 74:199-212.

Zagwijn, W.H., 1986. Nederland in het Holoceen. Rijks Geologische Dienst (Haarlem): 46 pp. 